\title{
Dengue type 3 virus infections in European travellers returning from the Comoros and Zanzibar, February- April 2010
}

P Gautret (surveillance@eurotravnet.eu) ${ }^{1,2}$, F. Simon ${ }^{2}$, H Hervius Askling ${ }^{3}$, 0 Bouchaud ${ }^{4}$, I Leparc-Goffart L L Ninove $^{6}$, P Parola $^{1}$, for EuroTravNet ${ }^{1}$

1. Infectious and Tropical Diseases Unit, Hospital Nord, Marseille, France

2. Infectious and Tropical Diseases Unit, Military Hospital Lavéran, Marseille, France

3. Department of Infectious Diseases, Karolinska University Hospital, Stockholm, Sweden

4. Infectious and Tropical Diseases Unit, Avicenne Hospital, Bobigny, France

5. Associated National Reference Center for Arboviruses, IRBA-IMTSSA, Marseille, France

6. Virology Laboratory, AP-HM Timone, Marseille, France

Citation style for this article:

Citation style for this article: Gautret P, Simon F, Hervius Askling H, Bouchaud O, Leparc-Goffart I, Ninove L, Parola P, for EuroTravNet. Dengue type 3 virus infections in European travellers returning from the Comoros and Zanzibar, February-April 2010. Euro Surveill. 2010;15(15):pii=19541. Available online: http://www. eurosurveillance.org/ViewArticle.aspx?Articleld=19541

This article has been published on 15 April 2010

In late February-early April 2010, five cases of dengue fever were diagnosed in returning travellers in Europe in EurotravNet sites in Sweden and France in patients with travel history to the Comoros and/or Zanzibar, Tanzania. Four cases were non-complicated dengue fever and one case dengue hemorrhagic fever. Three patients were viraemic at the time of diagnosis and infected with Dengue type 3 virus.

An estimated 100 million cases of dengue fever and 250,000 cases of dengue haemorrhagic fever occur annually worldwide [1]. The past 20 years have seen a dramatic geographic expansion of epidemic dengue fever from Southeast Asia to the South Pacific Islands, the Caribbean, and the Americans. An increasing number of reports of dengue fever and associated illness among travellers to dengue virus-infected areas paralleled the changing epidemiology of dengue in local populations [1].

In 2010 (until 14 April), five cases of dengue fever including one case of dengue haemorrhagic fever, have been reported from EurotravNet sites in France and Sweden, in four travellers returning from the Comoros and one traveller returning from Zanzibar, Tanzania. EurotravNet, the Network for travel medicine and tropical diseases of the European Centre for Disease Control consists of 14 core sites in nine European countries and participants monitor travel related infectious diseases in Europe (www.eurotravnet.eu).

\section{Case reports}

Cases were diagnosed in Paris (1 case) and Marseille (3 cases), France and Stockholm, Sweden (1 case). The age of cases ranged from 41 to 69 years, three were females, two males. All travellers to the Comoros had visited friends and relatives where they had stayed between 15 and 93 days in the period from December to March. The case returning from Zanzibar who had travelled as a tourist, had stayed for two days in Stone Town and seven days in Nungwy. All cases were noncomplicated dengue except for one case of dengue hemorrhagic fever. Detailed clinical presentations and onset of symptoms after return and laboratory findings are displayed in table 1.

Cases were confirmed by serology and four were positive for IgM and IgG and once case positive for IgM only. Three cases were confirmed as dengue type 3 virus (DENV-3) by PCR.

\section{Discussion and conclusion}

Six autochthonous cases of dengue fever were recently identified in the Comoros (March 2010). Additional cases were identified in individuals with travel history from the Comoros, in Madagascar (1 case), Mayotte (3 cases) and Reunion Island (1 case) $[1,2]$. In addition, two cases were potentially imported from Tanzania to Japan $[2,3]$. DENV-3 was identified in the cases in Madagascar and Japan. These results indicate that DENV-3 is currently circulating in the Comoros and Zanzibar, and given that the last outbreak in the Comoros took place in 1993 and involved DENV-1,[4] we may face a situation with the possibility for the emergence of a new outbreak including possible severe cases, similarly to what was recently observed in Sri-Lanka, East Africa and Latin America [5].

In order to protect themselves, travellers to areas where vector-borne diseases such as dengue fever and malaria are present should be advised to adopt some protective measures to avoid mosquito bites. Moreover, physicians should be prepared to diagnose and manage imported cases of dengue fever in travellers returning from the Comoros and East Africa early. Viraemic patients may spread the infection to regions where competent vectors are present, including the Mediterranean area and the south of Europe. 
In metropolitan France, dengue fever is a mandatory notifiable disease since Aedes albopictus has become established in the Mediterranean French littoral in 2004 and in Corsica in 2006 [6].

A. albopictus were found in August 2009, in the centre of Marseille [7]. Given the intensity of population flows between the Comoros and Marseille, especially during summer, early detection of viraemic travellers and entomological surveillance are critical. The establishment of $A$. albopictus, the vector for dengue and chikungunya viruses, in the south of Europe and the presence of viraemic imported cases of dengue fever in these regions could lead to autochthonous transmission [8]. In 2007, a viraemic patient infected with chikungunya virus was the source of an outbreak of chikungunya in Emilia-Romagna, Italy, with 205 cases occurring between 4 July and 27 September 2007 [9]. So far no sustained outbreaks from imported dengue fever or chickungunya have occurred but vigilance is needed.

Our report confirms that returning travelers may serve as sentinels for local outbreaks of dengue fever in endemic areas [10]. Finally, the case presenting exclusively with fever and without additional symptoms commonly associated with dengue fever, illustrates that dengue fever should be included early in the differential diagnosis in febrile travellers particularly when returning from areas with potential transmission of the disease [11].

\section{References}

1. Schwartz E, Weld LH, Wilder-Smith A, von Sonnenburg F, Keystone, JS, Kain KC, et al., for the GeoSentinel Surveillance Network. Seasonality, annual trends, and characteristics of dengue among ill returned travelers, 1997-2006. Emerg Infect Dis. $2008 ; 14(7): 1081-8$.

2. Dengue/DHF update 2010 (15). In: Promed-mail [online]. Boston US: International Society for Infectious Diseases: 23 March 2010. Archive no. 20100323.0922. Available from: http://www. promedmail.org/pls/apex/f?p=2400:1202:51849094839886 40::NO::F2400_P1202_CHECK_DISPLAY,F2400_P1202_PUB_ MAIL_ID:X,81876

3. Institut de Veille Sanitaire (InVS). [Alerte dengue dans le sud-ouest de l'Océan Indien. Point épidémiologique $\mathrm{N}^{\circ} 07$ au 25 mars 2010]. [French]. Available from: http://www. invs.sante.fr/surveillance/dengue/asie_se_ocean_indien/ pe_dengue_250310.pdf

4. Boisier P, Morvan JM, Laventure S, Charrier N, Martin E, Ouledi $A$, et al. [Dengue 1 epidemic in the Grand Comoro Island (Federal Islamic Republic of the Comoros). March-May 1993]. Ann Soc Belge Med Trop. 1994. 74(3): 217-29. [French].

5. Messer WB, Gubler DJ, Harris E, Sivananthan K, de Silva AM. Emergence and global spread of dengue serotype S, subtype III virus. Emerg Infect Dis. 2003;9(7):800-9.

6. Delaunay P, Jeannin C, Schaffner F, Marty P. [News on the presence of the tiger mosquito Aedes albopictus in metropolitan France]. Arch Ped. 2009;16 Suppl 2:S66-S71. [French].

7. Entente Interdepartementale pour la demoustication du littoral Mediterranéen (EID) Méditerranée. [Enquête entomologique dans le cadre de la surveillance d'Aedes albopictus]. 5/10/2009. Marseille (13) Compte-rendu d'intervention. Internal document. [French].

8. Soumahoro MK, Fontenille D, Turbelin C, Pelat C, Boyd A, Flahault $A$, et al. Imported chikungunya virus infection. Emerg Infect Dis. 2010;16(1):162-3.

\section{TABLE}

Clinical characteristics dengue fever in travellers returning from the Comoros and Zanzibar (Tanzania), February-April $2010(n=5)$

\begin{tabular}{|c|c|c|c|c|c|}
\hline & Case 1 & Case 2 & Case 3 & Case 4 & Case 5 \\
\hline Clinical symptoms & $\begin{array}{c}\text { Fever, shivering, } \\
\text { myalgias }\end{array}$ & $\begin{array}{l}\text { Fever, arthralgias, myalgias, } \\
\text { diarrhoea, headache, seizures, } \\
\text { bleeding (haematemesis, ulor- } \\
\text { rhagia, metrorrhagia) }\end{array}$ & Fever & $\begin{array}{l}\text { Fever, shivering, ar- } \\
\text { thralgias, myalgias, } \\
\text { headaches, diffused } \\
\text { non-petechial rash }\end{array}$ & $\begin{array}{c}\text { Fever, shivering, } \\
\text { anorexia, cough, } \\
\text { diarrhoea }\end{array}$ \\
\hline $\begin{array}{l}\text { Onset after return } \\
\text { (in days) }\end{array}$ & 7 & 4 (before return) & 1 & 0 & 0 \\
\hline Leucocyte count $/ \mu \mathrm{L}$ & 5,280 & 2,300 & 3,200 & 4,900 & 7,500 \\
\hline Platelet count/ $\mu \mathrm{L}$ & 83,000 & 34,000 & 15,500 & 13,000 & 56,000 \\
\hline SGOT (U/L) & 214 (norm 4.6) & 257 (norm 6.5) & Not available & 506 (norm 10.1) & 214 (norm 4.6) \\
\hline SGPT (U/L) & 125 (norm 1.9) & $183($ norm 4.5$)$ & Not available & 191 (norm 3.2) & 101 (norm 1.5) \\
\hline GGT (U/L) & 54 (norm 1.5) & $70($ norm 2.3) & Not available & $278($ norm 4.6$)$ & 47 (norm 1.3) \\
\hline $\mathrm{LDH}(\mathrm{U} / \mathrm{L})$ & 785 (norm 1.6) & 1,221 (norm 3.2) & Not available & 2,199 (norm 3.5) & 765 (norm 1.6) \\
\hline Serology & $\lg M+\lg G^{a}$ & $\lg M+\lg G^{b}$ & $\lg M+\lg G^{c}$ & $\lg M^{d}$ & $\lg M+\lg G^{a}$ \\
\hline PCR & Negative & DENV-3 ${ }^{\mathrm{e}}$ & Not available & DENV- $3^{e}$ & DENV- $3^{\mathrm{e}}$ \\
\hline
\end{tabular}

DENV-3: Dengue virus type 3; GGT: Gamma-glutamyl transpeptidase; LDH: Lactate dehydrogenase; norm: normal upper value; SGOT: Serum glutamic oxaloacetic transaminase; SGPT: Serum glutamic pyruvic transaminase.

${ }^{a}$ Detected by in house enzyme-linked immunosorbent assay (Associated National Reference Center for arboviruses IRBA-IMTSSA, Marseille). ${ }^{b}$ Panbio ELISA IgM and IgG (rapid test dengue duo Ig M and Ig G Panbio negative); ElA Biotrin Ig M (1.7; N< 1.5) and Ig G (3.6; N 1.5). 'Dengue IgM specific for dengue virus was detected (54 PBU; $\geq 11$ PBU positive) by ELISA (Dengue IgM PanBio) and high levels of dengue IgG was detected with IFI.

${ }^{d}$ Detected by indirect immunofluorescence (IFI) test (Standard Diagnostics Dengue Duo) and confirmed by ELISA (Panbio Dengue DUO Test).

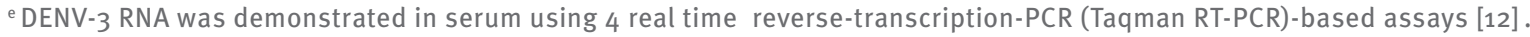


9. Rezza G, Nicoletti L, Angelini R, Romi R, Finarelli AC, Panning $M$, et al. ; CHIKV study group. Infection with chikungunya virus in Italy: an outbreak in a temperate region. Lancet. 2007;370(9602):1840-6.

10. Ninove L, Parola P, Baronti C, De Lamballerie X, Gautret $P$, Doudier B, et al. Dengue virus type 3 infection in traveler returning from west Africa. Emerg Infect Dis. 2009;15(11):1871-2.

11. Askling HH, Lesko B, Vene S, Berndtson A, Björkman P, Bläckberg J, et al. Serologic analysis of returned travelers with fever, Sweden. Emerg Infect Dis. 2009;15(11):1805-8.

12. Leparc-Goffart I, Baragatti M, Temmam S, Tuiskunen A, Moureau G, Charrel R, et al. Development and validation of real-time one-step reverse transcription-PCR for the detection and typing of dengue viruses. J Clin Virol. 2009; 45(1):61-6. 